\title{
Surface Characterization and Cell Response of Binary Ti-Ag Alloys with CP Ti as Material Control
}

\author{
B.B. Zhang ${ }^{1,2)}$, K.J. Qiu ${ }^{1,2)}$, B.L. Wang ${ }^{1)}$, L. Li ${ }^{1)}$ and Y.F. Zheng ${ }^{1,2) \dagger}$ \\ 1) Center for Biomedical Materials and Engineering, Harbin Engineering University, Harbin 150001, China \\ 2) Department of Materials Science and Engineering, College of Engineering, Peking University, Beijing 100871, China \\ [Manuscript received July 6, 2012, in revised form August 14, 2012]
}

\begin{abstract}
In this study, the surface passive films, dissolution behavior and biocompatibility of $\mathrm{Ti}-\mathrm{Ag}$ alloys (with $5 \%$, $10 \%$ and $20 \% \mathrm{Ag}$ ) were evaluated by X-ray diffraction (XRD) tests, electrochemical corrosion tests, X-ray photoelectron spectroscopy (XPS) tests, dissolution tests and in-vitro cytotoxicity tests. The surface films on the $\mathrm{Ti}-20 \mathrm{Ag}$ alloy are rich in $\mathrm{Ti}$ and much deficient in $\mathrm{Ag}$ with respect to alloy composition, as identified by XPS. Compared to $\mathrm{CP} \mathrm{Ti}, \mathrm{Ti}-5 \mathrm{Ag}$ and $\mathrm{Ti}-20 \mathrm{Ag}$ alloys show larger impedances and lower capacitances, which can be associated with an increase of the passive layer thickness. Moreover, all $\mathrm{Ti}-\mathrm{Ag}$ alloys exhibit negligible or low metal release in the test solutions. The in-vitro cytotoxicity results show $\mathrm{Ti}-\mathrm{Ag}$ alloys seem to be as cytocompatible as CP Ti. From the viewpoint of surface passive film and cytotoxicity, $\mathrm{Ti}-5 \mathrm{Ag}$ and $\mathrm{Ti}-20 \mathrm{Ag}$ are considered to be more suitable for dental applications.
\end{abstract}

KEY WORDS: Ti-Ag alloy; Surfaces; Electrochemical corrosion; Cytotoxicity

\section{Introduction}

Commercially pure titanium (CP Ti) has long been used as dental materials because of its good corrosion resistance and excellent biocompatibility ${ }^{[1,2]}$. However, the application of $\mathrm{CP} \mathrm{Ti}$ has raised some concerns due to the insufficient strength and poor wear resistance. Recently, $\mathrm{Ti}-\mathrm{Ag}$ dental alloys were developed and a systematic study on the mechanical behavior $^{[3,4]}$ and corrosion resistance ${ }^{[5,6]}$ was carried out. Based on the results reported, $\mathrm{Ti}-\mathrm{Ag}$ alloys are believed to be an excellent candidate for dental materials.

As easy to be understood, dental materials to be used as permanent implants in the human body must be corrosion resistant and tissue compatible. In our previous study ${ }^{[6,7]}$, addition of $\mathrm{Ag}$ to $\mathrm{Ti}$ is found to be effective in reducing the corrosion current density and increasing the open circuit potential of $\mathrm{Ti}$ in artificial saliva environment. Moreover, tita-

† Corresponding author. Prof., Ph.D.; Tel./Fax: +86 10 62767411; E-mail address: yfzheng@pku.edu.cn (Y.F. Zheng). nium/silver coatings consisting of both titanium and silver phases show low ion release rate and little cytotoxical effects ${ }^{[8]}$.

In order to understand the nature and growth pattern of the films formed on $\mathrm{Ti}-\mathrm{Ag}$ alloys, X-ray photoelectron spectroscopy (XPS) analysis, open circuit potential tests and electrochemical impedance spectroscopy (EIS) tests were carried out. Furthermore, dissolution behavior and cytotoxicity of $\mathrm{Ti}-\mathrm{Ag}$ alloys were characterized, thereby to develop new $\mathrm{Ti}-\mathrm{Ag}$ alloys with good corrosion resistance and biocompatibility.

\section{Materials and Method}

$\mathrm{Ti}-x \mathrm{Ag}$ binary alloys ( $x=5,10$ and 20 , in wt\%) were prepared from grade zero titanium, silver wire (99.9\% in purity) by arc melting in argon atmosphere. The button ingots were re-melted four times for homogeneity. For XPS tests, dissolution tests and cytotoxicity tests, specimens $(10 \mathrm{~mm} \times 10 \mathrm{~mm} \times 1 \mathrm{~mm})$ were polished step by step till using $2000 \#$ silicon carbide paper, and then ultrasonically cleaned with acetone for 10 min. XPS analysis was performed with a PHI 
S5700 XPS system using mono $\mathrm{Al} K \alpha(1486.6 \mathrm{eV})$ radiation at vacuum pressure of $10^{-4} \mathrm{~Pa}$. Multiplex (narrow-scan) spectra were obtained with the pass energy of $29.35 \mathrm{eV}$ for $\mathrm{O} 1 s, \mathrm{Ag} 3 d$ and $\mathrm{Ti} 2 p$ peaks.

In the electrochemical corrosion tests, the cell used was conventional three-electroded configuration with a $\mathrm{Pt}$ electrode and a saturated calomel electrode (SCE) as the counter electrode and reference electrode, respectively. All the measurements were carried out on an electro-chemical workstation (CHI660C, China). The test solution was Fuayama Mayer artificial saliva $(\mathrm{NaCl} 0.4 \mathrm{~g} / \mathrm{L} ; \mathrm{KCl} 0.4 \mathrm{~g} / \mathrm{L}$; $\mathrm{CaCl}_{2} 0.6004 \mathrm{~g} / \mathrm{L} ; \mathrm{NaH}_{2} \mathrm{PO}_{4} \cdot 2 \mathrm{H}_{2} \mathrm{O} 0.78 \mathrm{~g} / \mathrm{L} ; \mathrm{KSCN}$ $0.300 \mathrm{~g} / \mathrm{L} ; \mathrm{Na}_{2} \mathrm{~S} \cdot 9 \mathrm{H}_{2} \mathrm{O} 0.005 \mathrm{~g} / \mathrm{L}$; urea $\left.1.000 \mathrm{~g} / \mathrm{L}\right)$.

In the corrosion potential tests, the specimens were submerged into the electrolyte without any imposed potential for $7200 \mathrm{~s}$. The variations of the corrosion behavior during the formation of the passive film on the surface of the samples were studied by electrochemical impedance spectroscopy (EIS) technique. The impedance spectra were acquired in the frequency range of $10^{4}-10^{-2} \mathrm{~Hz}$ with a $10 \mathrm{mV}$ amplitude sine wave at open circuit potential.

Three solutions were prepared for the dissolution tests. One was Fuayama Mayer artificial saliva as mentioned above. One was $1 \%$ lactic acid solution (the $\mathrm{pH}$ is about 2.1). The other was $0.1 \mathrm{~mol} / \mathrm{L}$ $\mathrm{H}_{2} \mathrm{O}_{2}+0.9 \% \mathrm{NaCl}$ solution ( $\mathrm{pH} 4.0$ adjusted by lactic acid to accelerate the corrosion rate). Lactic acid could be formed in dental plaques, and $\mathrm{H}_{2} \mathrm{O}_{2}$ is likely to be generated in the body in the case of inflammation in the surrounding of implant or present in mouth washes. Specimens with the dimension of $10 \mathrm{~mm} \times 10 \mathrm{~mm} \times 1 \mathrm{~mm}$ were immersed in a 7 -mL test solution at $37{ }^{\circ} \mathrm{C}$ for $168 \mathrm{~h}$. The inductively coupled plasma atomic emission spectrometry (Leeman, Profile ICP-AES) was employed to measure the concentrations of titanium and silver ions, which had dissolved from the experimental alloy plates. An average of three measurements was taken for each group. The composition of surfaces before and after immersion was identified by scanning electron microscopy (SEM, Quanta 200 FEI) with energy dispersive X-ray detector.

Indirect cytotoxicity test was carried out according to a standard procedure described in our previous work ${ }^{[9]}$ using murine fibroblast cells (L929 and NIH3T3 cells). L929 and NIH3T3 cells were cultured in Dulbecco's modified Eagle's medium (DMEM), which was supplemented with $10 \%$ fetal bovine serum (FBS), $100 \mathrm{U} / \mathrm{ml}$ penicillin and $100 \mu \mathrm{l} / \mathrm{ml}$ streptomycin. Extracts of the $\mathrm{Ti}-\mathrm{Ag}$ alloys were prepared using serum free DMEM medium as the extraction medium with the surface area/extraction medium ratio of $3 \mathrm{~cm}^{2} / \mathrm{ml}$ in a humidified atmosphere with $5 \% \mathrm{CO}_{2}$ at $37{ }^{\circ} \mathrm{C}$ for $72 \mathrm{~h}$. The control groups involved the use of DMEM medium as negative control, $10 \%$ dimethylsulfoxide (DMSO) medium as positive control and $\mathrm{CP} \mathrm{Ti}$ as material control.

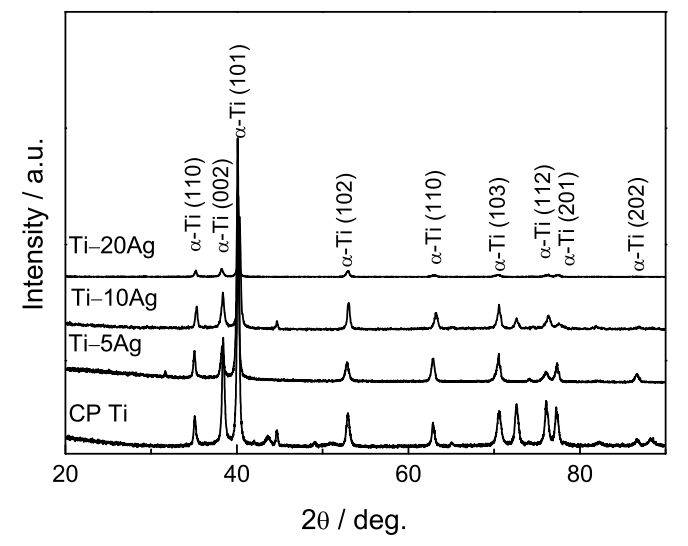

Fig. 1 XRD patterns of various $\mathrm{Ti}-\mathrm{Ag}$ alloys, with $\mathrm{CP}$ Ti as control

Cells were incubated in 96 well cell culture plates at $5 \times 10^{3}$ cells $/ 100 \mu \mathrm{l}$ medium in each well and incubated for $24 \mathrm{~h}$ to allow attachment. The medium was then replaced with $100 \mu \mathrm{l}$ of extracts. After 2, 4 and 7 days culture in a humidified atmosphere with $5 \% \mathrm{CO}_{2}$ at $37{ }^{\circ} \mathrm{C}$ in 96 well plates, $10 \mu \mathrm{l}$ 3-(4,5-Dimethylthiazol-2-yl)-2, 5-diphenyltetrazolium bromide (MTT, Sigma-Aldrich, America) was added to each well. The samples were incubated with MTT at $37^{\circ} \mathrm{C}$ for $4 \mathrm{~h}$ in darkness, and then $100 \mu \mathrm{l}$ formazan solubilization solution (10\% SDS in $0.01 \mathrm{~mol} / \mathrm{L} \mathrm{HCl})$ was added in each well overnight. The spectrophotometric absorbance of the samples was measured by microplate reader (Bio-RAD680) at $570 \mathrm{~nm}$ with a reference wavelength of $630 \mathrm{~nm}$.

\section{Results and Discussion}

\subsection{Phase identification}

Fig. 1 shows the X-ray diffraction (XRD) patterns of different $\mathrm{Ti}-\mathrm{Ag}$ alloys. The XRD patterns of $\mathrm{Ti}-$ Ag alloys are similar to those of CP Ti. It seems that the crystal structure of $\mathrm{Ti}-\mathrm{Ag}$ alloys is not sensitive to Ag content. No peaks of intermetallic compounds are detected, which is possibly attributed to the high cooling rate during the preparation.

\subsection{XPS surface analysis}

In practice, a very thin oxide film on the Ti surface plays a decisive role in determining the biocompatibility and corrosion behavior of the Ti implant ${ }^{[10]}$. In addition, surface modification is often used on titanium alloys to obtain enhanced wear resistance or high osseointegration ${ }^{[11]}$. The knowledge of the material's surface composition is absolutely necessary.

The survey spectra obtained from $\mathrm{CP} \mathrm{Ti}$ and $\mathrm{Ti}-$ $20 \mathrm{Ag}$ alloy with XPS are shown in Fig. 2. The oxide layers mainly consist of $\mathrm{TiO}_{2}$. The $[\mathrm{Ag}] /([\mathrm{Ti}]+[\mathrm{Ag}])$ ratio in the surface oxide film is about 0.019 , which is 


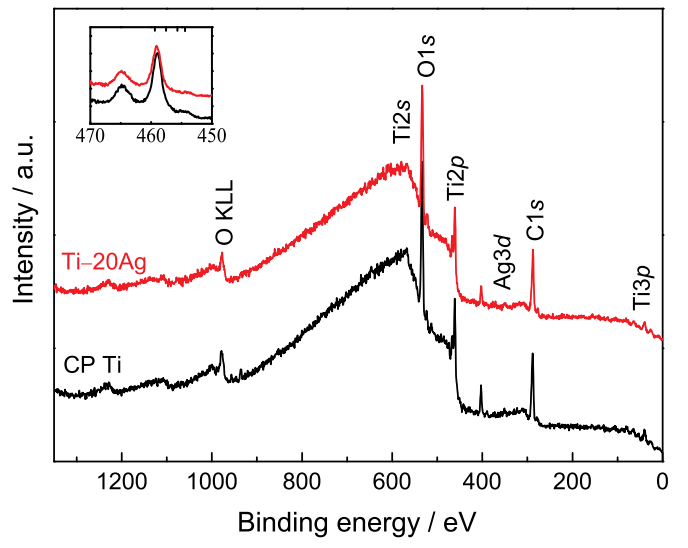

Fig. 2 XPS surface chemical analyses of CP Ti and Ti$20 \mathrm{Ag}$ alloy

significantly lower than that in the substrate (about 0.2 ). The inset in Fig. 2 shows enlarged images of the sections of the spectra for Ti at about $460 \mathrm{eV}$. Metallic Ti could be detected for $\mathrm{CP}$ Ti. This indicates that the surface oxide film is very thin because the metallic state of elements could be detected through the surface oxide film. In comparison, the metallic $\mathrm{Ti}$ peak for $\mathrm{Ti}-20 \mathrm{Ag}$ alloy is not obvious.

\subsection{Electrochemical behavior}

Fig. 3 presents the evolutions of the open-circuit potential of $\mathrm{CP} \mathrm{Ti}$ and $\mathrm{Ti}-\mathrm{Ag}$ alloys as a function of immersion time in the artificial saliva solution. For CP Ti, Ti-5Ag and $\mathrm{Ti}-20 \mathrm{Ag}$ alloys, corrosion potentials increased moderately during initial immersion and stabilized after $\sim 1000 \mathrm{~s}$. This phenomenon indicates the thickening of the passive oxide film. After $7200 \mathrm{~s}$ immersion, the corrosion potentials of $\mathrm{Ti}-$ $\mathrm{Ag}$ alloys are about $150 \mathrm{mV}$ higher than that of $\mathrm{CP}$ $\mathrm{Ti}$, and $\mathrm{Ti}-5 \mathrm{Ag}$ alloy shows the highest open circuit potential values compared to other alloys. The change in the corrosion potentials is considered to be caused by the addition of Ag. Similar results can be observed in $\mathrm{Ti}-\mathrm{Ag}$ binary alloys ${ }^{[5,6]}$ and $\mathrm{Ti}-\mathrm{Ag}-\mathrm{Cu}$ ternary alloys ${ }^{[12]}$. It is assumed thicker or more stable oxide films formed on $\mathrm{Ti}-\mathrm{Ag}$ based alloys.

The impedance spectra are present as Nyquist plots and Bode plots, as shown in Fig. 4. The nature of the Nyquist plots is similar for all the alloys, consisting of an arc that can be extrapolated to a semicircle, which is associated with the corrosion process. $\mathrm{Ti}-20 \mathrm{Ag}$ alloy exhibits the largest semicircle radius, suggesting the highest impedance.

In the Bode plots, a highly capacitive behavior, typical of passive materials, is indicated from medium to low frequencies by phase angles approaching -90 deg., suggesting that a highly stable film is formed on tested alloy in the electrolyte used ${ }^{[13]}$. Moreover, the intermediate frequency region $\left(10^{3}\right.$ to $10 \mathrm{~Hz}$ ) has the maximum phase angle and the

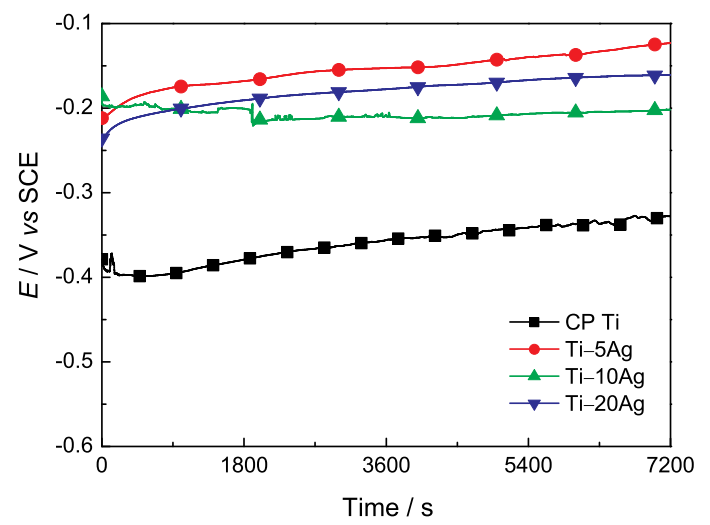

Fig. 3 Open circuit potential of $\mathrm{CP} \mathrm{Ti}$ and $\mathrm{Ti}-\mathrm{Ag}$ alloys in artificial saliva solution
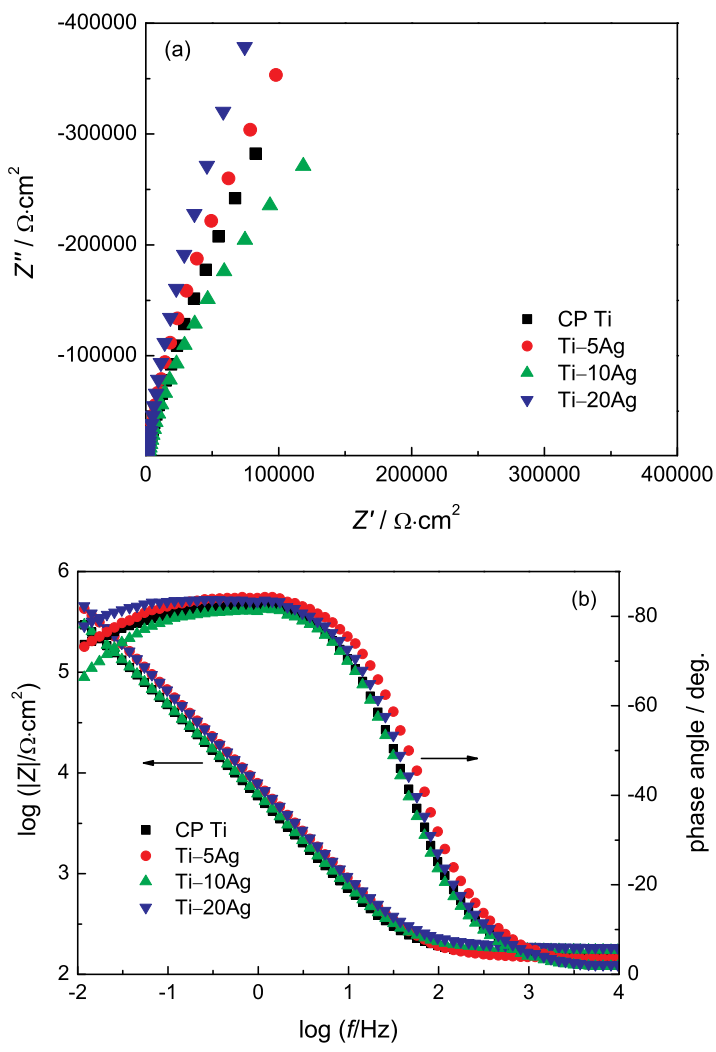

Fig. 4 Electrochemical impedance spectra of CP Ti and $\mathrm{Ti}-\mathrm{Ag}$ alloys immersed in artificial saliva solution: (a) Nyquist plots, (b) Bode plots

$\log |Z|$ vs $\log f$ slope approaching -1 . Those impedance responses correspond to the capacitive behavior of the electrode and describe the dielectric properties of the electronically conducting surface film.

According to the above EIS results obtained from CP Ti and Ti-Ag alloys, a $R_{\mathrm{s}}\left(Q_{1} R_{1}\right)$ model was used as the equivalent circuit model to fit the EIS data in the case of single passive film presented on the metal surface, as shown in Fig. $5(\mathrm{a}) . R_{\mathrm{S}}$ is the solution resistance; $R_{1}$ is the passive film resistance and $Q_{1}$ is the constant-phase element (CPE) for the passive film. 
Table 1 Electrochemical impedance parameters of CP $\mathrm{Ti}$ and $\mathrm{Ti}-\mathrm{Ag}$ alloys in artificial saliva solution

\begin{tabular}{cccccc}
\hline Materials & $R_{\mathrm{s}} /\left(\Omega \cdot \mathrm{cm}^{2}\right)$ & $Q_{1} /\left(\mathrm{F} / \mathrm{cm}^{2}\right)$ & $n$ & $R_{1} /\left(\Omega \cdot \mathrm{cm}^{2}\right)$ & $\chi^{2}$ \\
\hline CP Ti & 155.8 & $3.30 \times 10^{-5}$ & 0.92 & $1.65 \times 10^{6}$ & $8.5 \times 10^{-4}$ \\
Ti-5Ag & 146.0 & $2.37 \times 10^{-5}$ & 0.93 & $2.10 \times 10^{6}$ & $7.3 \times 10^{-4}$ \\
Ti-10Ag & 175.6 & $3.19 \times 10^{-5}$ & 0.91 & $0.99 \times 10^{6}$ & $6.7 \times 10^{-4}$ \\
Ti-20Ag & 186.3 & $2.37 \times 10^{-5}$ & 0.93 & $4.82 \times 10^{6}$ & $5.0 \times 10^{-4}$ \\
\hline
\end{tabular}

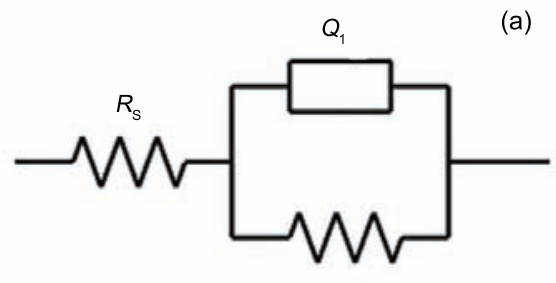

$R_{1}$

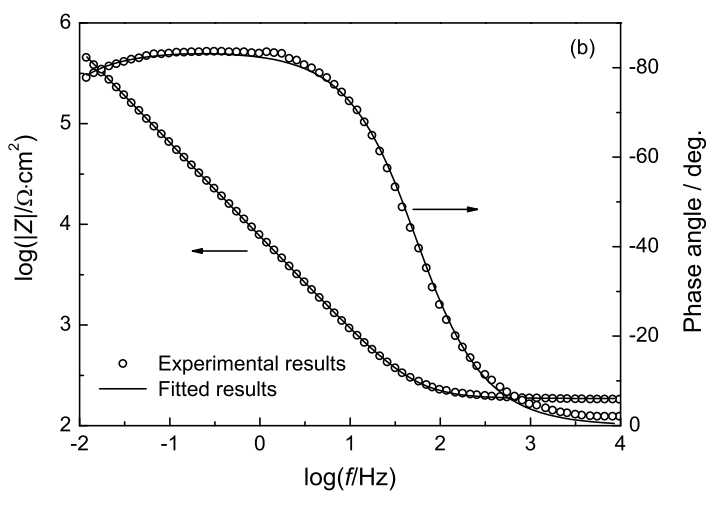

Fig. 5 Equivalent circuit fitted for $\mathrm{Ti}-\mathrm{Ag}$ alloys (a) and fitted Bode impedance spectra of $\mathrm{Ti}-20 \mathrm{Ag}$ alloy immersed artificial saliva solution (b)

This model has been widely discussed for the single passive layer formed on the surface of titanium alloys ${ }^{[14,15]}$.

Good agreement between the experimental data and fitted data was obtained, as shown in Fig. 5(b) and the fitted parameters are shown in Table $1 . Q_{1}$ and $n$ are the magnitude and the exponent of the constant phase element, respectively. The good consistence between the experimental data and fitted data was obtained with the $\chi^{2}$ of about $10^{-4}$. Large values of $R_{1}$ (of the order of $1 \times 10^{6} \Omega \cdot \mathrm{cm}^{2}$ ) are obtained, confirming the formation of a passive film of $\mathrm{CP} \mathrm{Ti}$ and $\mathrm{Ti}-\mathrm{Ag}$ alloys. It is also observed that the $n$ values are high, more than 0.9 , which indicates that the passive film exhibits a near capacitive behavior. It is interesting that $\mathrm{Ti}-5 \mathrm{Ag}$ alloy and $\mathrm{Ti}-20 \mathrm{Ag}$ alloy give larger impedances and lower capacitances than CP Ti. Large impedances and low capacitances can be associated with an increase of the passive layer thickness $\left.{ }^{[16}\right]$. However, Ti-10Ag alloy exhibits the lowest impedance.

Moreover, it can be seen that the values of $n$ were very close to $1(n>0.9)$ for all the alloys. This indicates a near capacitive behavior of the passive films formed on $\mathrm{CP} \mathrm{Ti}$ and $\mathrm{Ti}-\mathrm{Ag}$ alloys ${ }^{[17]}$.
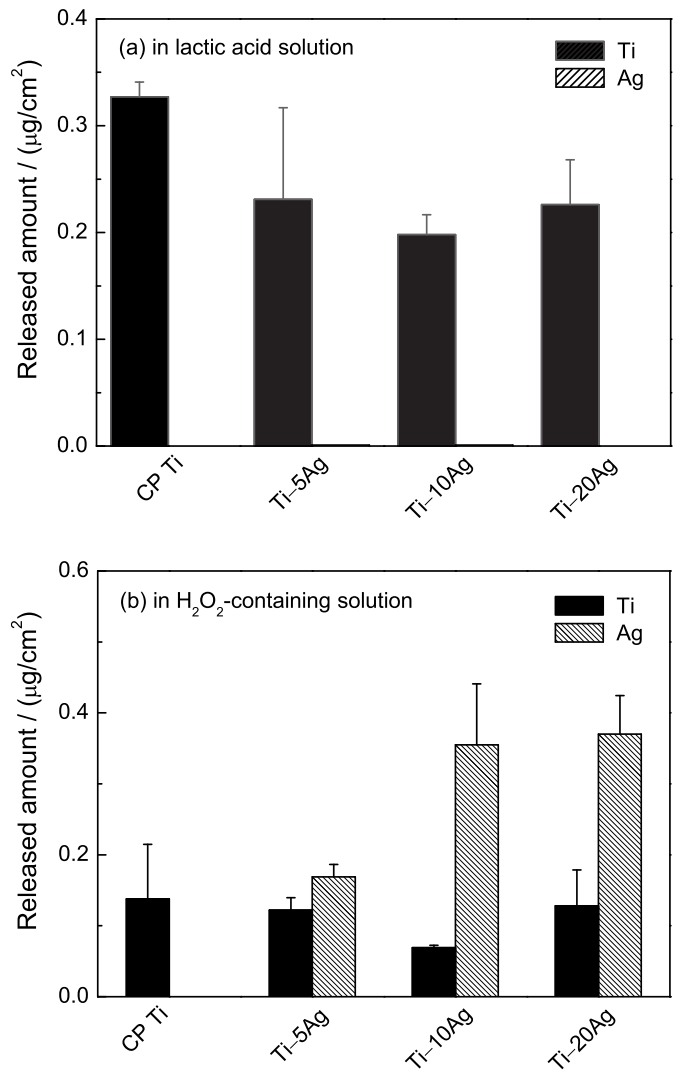

Fig. 6 Ion released behavior of $\mathrm{Ti}-\mathrm{Ag}$ alloys in different solutions: (a) lactic acid solution, (b) $\mathrm{H}_{2} \mathrm{O}_{2}$ containing solution, with $\mathrm{CP} \mathrm{Ti}$ as material control

Compared to $R_{1}$ values, the $R_{\mathrm{s}}$ values obtained are relatively low and do not vary notably for different alloys.

\subsection{Dissolution behavior and surface analysis}

Fig. 6 shows the comparison of the amount of $\mathrm{Ti}$ and $\mathrm{Ag}$ ions released from $\mathrm{Ti}-\mathrm{Ag}$ alloys after $7 \mathrm{~d} \mathrm{im}-$ mersion in lactic acid solution (Fig. 6(a)) and $\mathrm{H}_{2} \mathrm{O}_{2}-$ containing solution (Fig. 6(b)). In artificial saliva solution, the $\mathrm{Ti}$ and $\mathrm{Ag}$ quantities released are very low and below the detection limit of ICP-AES, so the data are not shown.

In lactic acid solution and $\mathrm{H}_{2} \mathrm{O}_{2}$-containing solution, all alloys exhibited very low ion releaseed amount, suggesting that $\mathrm{Ti}-\mathrm{Ag}$ alloys are corrosionresistant metal in the test solutions ${ }^{[18]}$. The quantity of $\mathrm{Ti}$ ions released from $\mathrm{CP} \mathrm{Ti}$ is the highest in both solutions. In lactic acid solution, the $\mathrm{Ag}$ concentration is under the detection limit for 

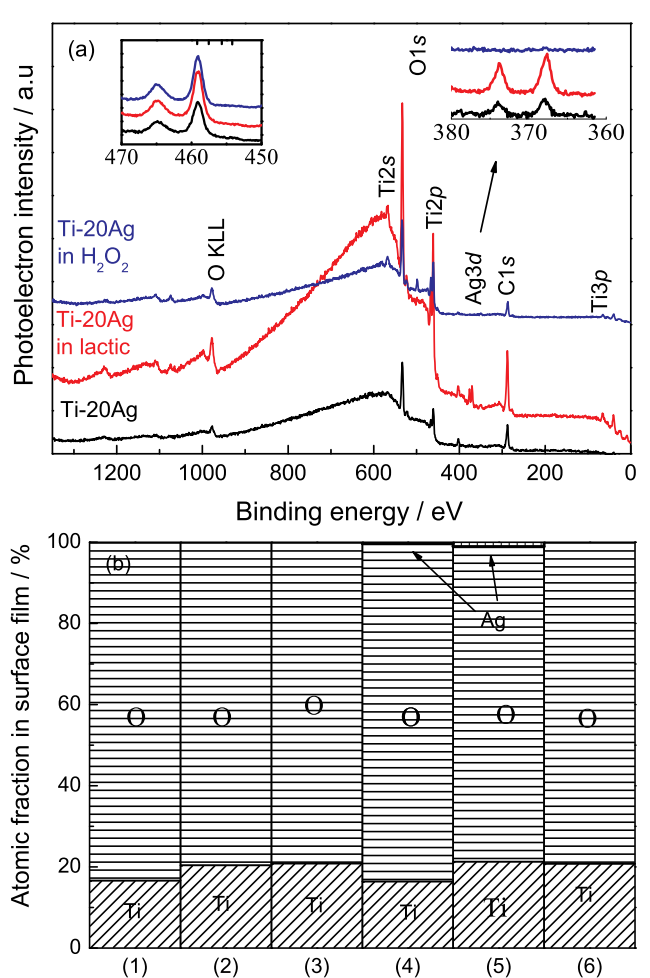

Fig. 7 XPS surface chemical analyses of $\mathrm{CP} \mathrm{Ti}$ and $\mathrm{Ti}-$ $20 \mathrm{Ag}$ alloy before and after immersed in $\mathrm{H}_{2} \mathrm{O}_{2}$ solution: (a) XPS survey spectrum, (b) the changes in atomic fractions in the alloy surface. (1), (2), $(3),(4),(5)$ and (6) represent non-treated $\mathrm{CP} \mathrm{Ti}$, $\mathrm{CP}$ Ti immersed in lactic acid solution, CP Ti immersed in $\mathrm{H}_{2} \mathrm{O}_{2}$-containing solution, non-treated $\mathrm{Ti}-20 \mathrm{Ag}$ alloy, $\mathrm{Ti}-20 \mathrm{Ag}$ alloy immersed in lactic acid solution and $\mathrm{Ti}-20 \mathrm{Ag}$ alloy immersed in $\mathrm{H}_{2} \mathrm{O}_{2}$-containing solution, respectively

all $\mathrm{Ti}-\mathrm{Ag}$ alloys. CP Ti shows remarkable dissolution, whereas $\mathrm{Ti}-10 \mathrm{Ag}$ alloy shows the least dissolution. $\mathrm{Ti}-5 \mathrm{Ag}$ and $\mathrm{Ti}-20 \mathrm{Ag}$ alloys showed slightly higher dissolution than $\mathrm{Ti}-10 \mathrm{Ag}$ alloy. In $\mathrm{H}_{2} \mathrm{O}_{2}$-containing solution, the amount of $\mathrm{Ag}$ ions dissolved from $\mathrm{Ti}-\mathrm{Ag}$ alloys increase with increasing $\mathrm{Ag}$ content. $\mathrm{Ti}-10 \mathrm{Ag}$ alloy and $\mathrm{Ti}-20 \mathrm{Ag}$ alloy exhibit similar total ion released amount.

According to the results obtained, $\mathrm{Ti}-\mathrm{Ag}$ alloys do not release elements in proportion to its composition. The different quantities of the alloying element released depend on the type of solution. The released amount of $\mathrm{Ag}$ ions in lactic acid solution was mostly not detectable, namely under the minimal detection limit of ICP-AES, for all $\mathrm{Ti}-\mathrm{Ag}$ alloys tested in lactic acid solution. In comparison, a significant $\mathrm{Ag}$ released amount is observed with the $\mathrm{H}_{2} \mathrm{O}_{2}$-containing solution.

In order to elucidate the surface-related chemical characteristics of the alloy, XPS analysis was performed for the $\mathrm{CP} \mathrm{Ti}$ and $\mathrm{Ti}-20 \mathrm{Ag}$ alloy after immersion in lactic acid solution and $\mathrm{H}_{2} \mathrm{O}_{2}$-containing solution, and the spectra are shown in Fig. 7(a). After $7 \mathrm{~d}$ immersion, according to the fractions, $\mathrm{TiO}_{2}$ is pre-

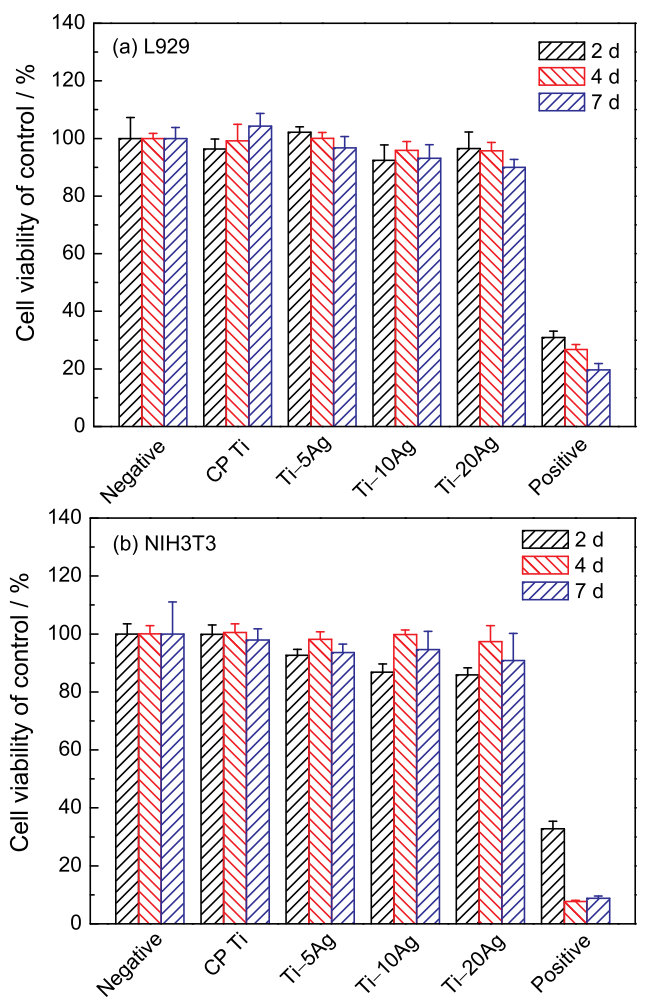

Fig. 8 Cell viability expressed as a percentage of the viability of cells in the negative control after 2, 4 and $7 \mathrm{~d}$ of culture in $\mathrm{CP} \mathrm{Ti}$ and experimental $\mathrm{Ti}-\mathrm{Ag}$ alloys extraction mediums: (a) L929 cell line, (b) NIH3T3 cell line

dominant state in the surface oxide. Little amounts of suboxide components could be found either coexisting with the $\mathrm{TiO}_{2}$ phase or lying directly beneath this phase. For Ti-20Ag alloy after immersion in $\mathrm{H}_{2} \mathrm{O}_{2}$ containing solution, no peak corresponding to $\mathrm{Ag}$ is detected.

Fig. 7(b) shows the atomic fraction of elements in the surface for $\mathrm{CP} \mathrm{Ti}$ and $\mathrm{Ti}-20 \mathrm{Ag}$ alloy before and after immersion in various solutions. The air-formed oxide film on the $\mathrm{Ti}-20 \mathrm{Ag}$ alloy is rich in $\mathrm{Ti}$ and much deficient in $\mathrm{Ag}$ with respect to alloy composition. When the alloy is immersed in $\mathrm{H}_{2} \mathrm{O}_{2}$-containing solution, the fractions of $\mathrm{Ag}$ cations in the surface film decrease as compared with the air-formed surface composition. According to the ion release results shown in Fig. 6(b), it could be deduced that most of $\mathrm{Ag}$ cations released into the solution. EDX analyses confirm the releasing of Ag. For Ti-20Ag alloy, when compared to the mean nominal chemical composition (19.62 $\pm 0.12 \mathrm{wt} \%)$, a significant decrease in $\mathrm{Ag}$ content $(9.50 \pm 0.18 \mathrm{wt} \%)$ could be observed after immersed in $\mathrm{H}_{2} \mathrm{O}_{2}$-containing solution. On the contrary, $\mathrm{Ag}$ is moderately enriched in the alloy surface after immersion in lactic acid solution because of the release of $\mathrm{Ti}$.

\subsection{In-vitro cytotoxicity}

Fig. 8 shows the viability of murine fibroblast cells 


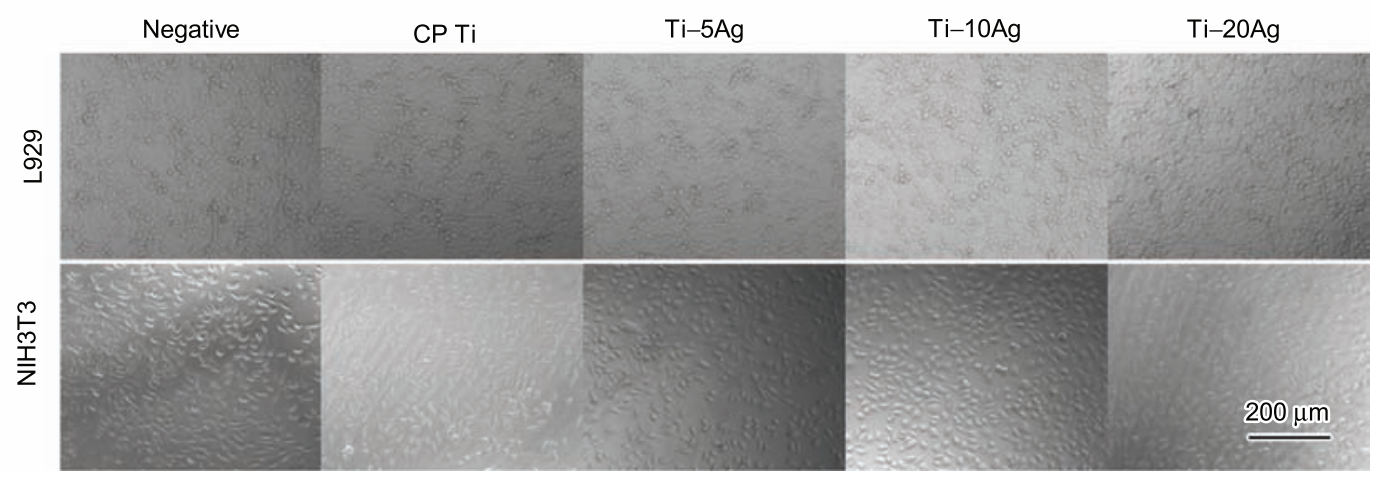

Fig. 9 Optical morphologies of L929 and NIH 3T3 cells cultured in the control, CP Ti and Ti-Ag alloys extraction medium for $7 \mathrm{~d}$

L929 (Fig. 8(a)) and NIH3T3 (Fig. 8(b)) cocultured with the extract of the experimental alloys and expressed as a percentage of the viability of cells cultured in negative control. For L929 fibroblasts, there are few differences in cell viability among negative control, $\mathrm{CP} \mathrm{Ti}$ and $\mathrm{Ti}-\mathrm{Ag}$ materials at any point in time. In the case of NIH3T3 fibroblast cells, the viability of cells cultured in $\mathrm{Ti}-\mathrm{Ag}$ alloy extracts slightly decreases compared to that cultured in $\mathrm{CP} \mathrm{Ti}$ for $2 \mathrm{~d}$, the cell viability decrease with increasing Ag content. After long time (4 and $7 \mathrm{~d}$ ) culture, $\mathrm{Ti}-\mathrm{Ag}$ alloy groups exhibit almost the same cell viability as $\mathrm{CP} \mathrm{Ti}$ group.

The morphologies of L929 and NIH3T3 cells cultured in the extraction media for $7 \mathrm{~d}$ are shown in Fig. 9. Most of the cells cultured in the extracts of $\mathrm{Ti}-\mathrm{Ag}$ alloys grow well and the cell proliferation has not been inhibited. The cells cultured in the extracts of $\mathrm{Ti}-\mathrm{Ag}$ alloys show a similar attachment and proliferation to the negative control. All in all, the viability and morphologies results suggest excellent cytocompatibility for the $\mathrm{Ti}-\mathrm{Ag}$ alloys.

\section{Conclusion}

In this study, $\mathrm{Ti}-\mathrm{Ag}$ alloys have been prepared and their surface films, dissolution behavior and cytotoxicity have been tested. In comparsion with $\mathrm{CP}$ $\mathrm{Ti}, \mathrm{Ti}-5 \mathrm{Ag}$ and $\mathrm{Ti}-20 \mathrm{Ag}$ alloys show higher corrosion potentials, larger impedances and lower capacitances, which can be associated with nobler electrochemical behavior. The total amounts of dissolved titanium from $\mathrm{Ti}-\mathrm{Ag}$ alloys are much less than that from $\mathrm{CP} \mathrm{Ti}$. The excellent corrosion resistance and the low level of dissolution are mainly attributed to the $\mathrm{TiO}_{2}$ film on the surface. The cytotoxicity tests show that $\mathrm{Ti}-\mathrm{Ag}$ alloys indicate similar cell viability to CP Ti. Because of their excellent corrosion resistance, low ion release amount and good biocompatibility, $\mathrm{Ti}-5 \mathrm{Ag}$ alloy and $\mathrm{Ti}-20 \mathrm{Ag}$ alloy are probably to be good candidate as dental materials and can be used for different dental devices.

\section{Acknowledgements}

This work was supported by the National Ba- sic Research Program of China ("973 Program", Nos. 2012CB619102 and 2012CB619100), the National High Technology Research and Development Program of China ("863 Program", Nos. 2011AA030101 and 2011AA030103), the National Natural Science Foundation of China (Nos. 31170909 and 51041004), the Research Fund for the Doctoral Program of Higher Education (No. 20100001110011), the Fundamental Research Funds for the Central Universities (Nos. HEUCFZ1017 and HEUCFR1020), and the Natural Science Foundation of Heilongjiang Province, China (No. ZD201012).

\section{REFERENCES}

[1 ] D.M. Brunette, P. Tengvall, M. Textor and P. Thomsen: Titanium in Medicine, Springer, Berlin, 2001.

[2] M. Niinomi: Mater. Sci. Eng. A, 1998, 243, 231.

[3 ] M. Takahashi, M. Kikuchi and Y. Takada: Dent. Mater. J., 2002, 21, 270.

[4] K.T. Oh, H.M. Shim and K.N. Kim: J. Biomed. Mater. Res. Part B, 2005, 74, 649.

[5 ] S.B. Hong, N. Eliaz, E.M. Sachs, S.M. Allen and R.M. Latanision: Corros. Sci., 2001, 43, 1781.

[6] B.B. Zhang, Y.F. Zheng and Y. Liu: Dent. Mater., 2008, 25, 672 .

[7 ] B.B. Zhang, B.L. Wang, L. Li and Y.F. Zheng: Dent. Mater., 2011, 27, 214.

[8 ] A. Ewald, S.K. Glückermann, R. Thull and U. Gbureck: Biomed. Eng. Online, 2006, 5, 22.

[9 ] X.N. Gu, Y. F. Zheng, Y. Cheng and S.P. Zhong: Biomaterials, 2009, 30, 484.

[10] A.P.R. Alves, F.A. Santana, L.A.A. Rosa, S.A. Cursino and E.N. Codaro: Mater. Sci. Eng. C, 2004, 24, 693 .

[11] M. Geetha, A.K. Singh, R. Asokamani and A.K. Gogia: Prog. Mater. Sci., 2009, 54, 397.

[12] D.K. Kang, S.K. Moon, K.T. Oh, G.S. Choi and K.N. Kim: J. Biomed. Mater. Res. Part B, 2009, 90, 446.

[13] S.L. de Assis, S. Wolynec and I. Costa: Electrochim. Acta, 2006, 51, 1815.

[14] B.L. Wang, Y.F. Zheng and L.C. Zhao: Mater. Corros., 2009, 60, 788.

[15] J.E.G. González and J.C. Mirza-Rosca: J. Electroanal. Chem., 1999, 471, 109.

[16] W.R. Osorio, A. Cremasco, P.N Andrade, A. Garcia and R. Caram: Electrochim. Acta, 2010, 55, 759.

[17] A.K. Shukla and R. Balasubramaniam: Corros. Sci., 2006, 48, 1696.

[18] Y. Okazaki and E. Gotoh: Biomaterials, 2005, 26, 11. 